\title{
Colorimetric Detection of Polynucleotides on Polypropylene Slices
}

\author{
Libo Nie,* Jianxin Tang, * Huishi Guo,* Hong Chen, ** Pengfeng XIaO,* and Nongyue He*† \\ *Key Laboratory of Molecular and Biomolecular Electronics (Southeast University), \\ Ministry of Education, Nanjing 210096, China \\ **Life Science and Technology Department of Central South Forestry University, Changsha 410004, China
}

\begin{abstract}
The gold-label-silver-stain method (GLSS) for DNA hybridization detection has been receiving increased interest as a colorimetric detective method, demonstrating the advantages of non-radioactivity, non-quenching effect of fluorescence and simplicity for analytical equipment. A colorimetric detection based on the GLSS method was applied to DNA arrays in situ synthesized on polypropylene (PP) slices. In this paper a simple plasma treatment was employed to graft amino $\left(-\mathrm{NH}_{2}\right)$ on the polypropylene slice surfaces, where DNA probes were immobilized via in situ synthesis. Hybridization was accomplished by a sandwich hybridization format. With the amplification of Silver Enhancer Solution, the hybridization signals were recorded with a scanner. A target DNA concentration as low as $100 \mathrm{fM}$ was detected. Complementary and mismatched sequences were clearly distinguished, and the ratio of the background-subtracted gray scale values for a perfect match, single-base mismatch, 2-base mismatch and 3-base mismatch is 22:16:9:4. The sensitivity of the in situ synthesis system was 3 orders of magnitude higher than that of the spotting system, and the signals of the former were about 2-times stronger than that of the latter under the same target DNA concentration.
\end{abstract}

(Received September 22, 2003; Accepted October 27, 2003)

\section{Introduction}

Gene-chip technology based on various matrixes and multiplicate detective methods has received much attention in recent years because of its application in the diagnosis of pathogenic and genetic disease. ${ }^{1}$ The gold label silver stain (GLSS) method developed three decades ago was first used in immune detection. In recent years it was applied to sequencespecific DNA detection, which has many desirable features, such as higher sensitivity and specificity compared with the fluorophore labeled method, as well as no radioactivity, no fluorescence quenching, and little or no required instrumentation..$^{2-4}$ Mirkin's group developed GLSS on a slide to detect spotted DNA arrays, and exploited it for electrical detection, as well as assembled gold nanoparticles connected with DNA into network materials. ${ }^{3-6}$

Because of its low cost, chemical and mechanical properties, ready availability in a number of different forms, and the great potential of the grafting technique to create reactive centers, the polymer is an attractive matrix for DNA immobilization. Many papers have been published on the immobilization of protein and DNA using nylon as a support substrate. ${ }^{7-11}$ To graft amino functions onto the surface of nylon, the reported chemical grafting methods are generally complicated. Here, polypropylene slices can be grafted by an amino $\left(-\mathrm{NH}_{2}\right)$ by a plasma treatment that is used as a DNA chip matrix.

The present work aims to develop colorimetric detection of polynucleotides on grafted polypropylene slices. The oligonucleotide-functionalized gold nanoparticles (gold-labeled probes) hybridize to target DNA that have been hybridized to

\footnotetext{
† To whom correspondence should be addressed.

E-mail: nyhe1958@163.com
}

DNA probes in situ synthesized on the surface of PP slices, which was the so-called sandwich assay format. ${ }^{4}$ With the amplification of Silver Enhancer Solution, the hybridization signals were recorded with a scanner. Such a GLSS colorimetric detection method demonstrated a promising viability to DNA array-based profiling.

\section{Experimental}

\section{Reagents}

$\mathrm{HAuCl}_{4} \cdot 3 \mathrm{H}_{2} \mathrm{O}$ was purchased from Shanghai Reagent Factory. MicroHyb hybridization buffer was purchased from Research Genetics. Alkanethiol-modified oligonucleotide, target oligonucleotide were purchased from Shanghai Shenyou Biotechnology Company. The sequences were as follows, respectively:

P1: 3'-TTTTCAAACTCTCGA-SH-5'

T0: 5'-ACATCGATGCACTGAGTGGAATGGAGGGCCGCA AGAAAAAGTTTGAGAGCT-3'

T1: 5'-ACATCGAAGCACTGAGTGGAATGGAGGGCCGCA AGAAAAAGTTTGAGAGCT-3'

T2: 5'-ACATCGTAGCACTGAGTGGAATGGAGGGCCGCA AGAAAAAGTTTGAGAGCT-3'

T3: 5'-ACATCGTACCACTGAGTGGAATGGAGGGCCGCA AGAAAAAGTTTGAGAGCT-3'

The deoxynucleoside phosphoramidites used in in situ synthesis were purchased from Transgenomic. All other reagents were all of analytical grade.

\section{Instrumentation}

A transmission electron microscopy (TEM) image was recorded with a JEM-200CX TEM. A Beckman J-30I centrifuge was used for the centrifugation of an Au nanoparticle 
solution. The superpure water used was purified with a Milli-Q water purification system. DNA probes were in situ synthesized with an Expedite 8909 DNA synthesizer. Silver stained images were recorded with a scanner.

\section{Preparation of Au nanoparticles}

The $13 \mathrm{~nm}$ diameter Au particles were prepared according to Frens ${ }^{1}$ method. All glassware was cleaned in aqua regia $\left(\mathrm{HCl}: \mathrm{HNO}_{3}=3: 1\right)$, rinsed with super-pure water, and dried. The $1 \%(\mathrm{w} / \mathrm{w}) \mathrm{HAuCl}_{4} \cdot 3 \mathrm{H}_{2} \mathrm{O}$ aqueous solution was prepared prior to use. Then $20.6 \mathrm{ml}$ of the $1 \% \mathrm{HAuCl}_{4}$ solution and 480 $\mathrm{ml}$ of superpure water were brought to a flask equipped with a condenser and a heater. The solution was heated to reflux with vigorous stirring. Then, $50 \mathrm{ml}$ of a $38.8 \mathrm{mM}$ trisodium citrate solution was quickly added. The color of the solution changed to deep red in a few seconds. After the color change, the solution was brought to reflux for $15 \mathrm{~min}$ continuously, and allowed to cool naturally to room temperature after moving away from the heater. Subsequently, the solution was filtered through a $0.45 \mu \mathrm{m}$ nylon membrane, then stored at $4^{\circ} \mathrm{C}$ in dark bottles. TEM determined the size of the nanoparticles (Fig. 1). The TEM indicated that the sizes of the nanoparticles were homogeneous, with a small deviation $(\sim 13 \pm 1 \mathrm{~nm})$.

Preparation of 5'-alkanethiol-capped oligonucleotide-modified Au nanoparticles

The gold nanoparticle-labeled probes were derived from mixing $2 \mathrm{ml}$ of the above-mentioned $13 \mathrm{~nm}$ diameter $\mathrm{Au}$ nanoparticle solution with 1 OD of (alkanethiol)oligonucleotide P1 (final oligonucleotide concentration is $3.51 \mu \mathrm{M}$ ). After being incubated for $16 \mathrm{~h}$ at room temperature, the solution was brought to $3 \mathrm{ml}$ of $0.1 \mathrm{M} \mathrm{NaCl}, 10 \mathrm{mM}$ phosphate buffer (pH 7) to stand for $48 \mathrm{~h}$, followed by centrifugation for $25 \mathrm{~min}$ at $14000 \mathrm{rpm}$ to get rid of unbound oligonucleotide. Following removal of the supernatant, the red precipitate was resuspended to $5 \mathrm{ml}$ of $0.1 \mathrm{M} \mathrm{NaCl}, 10 \mathrm{mM}$ phosphate buffer $(\mathrm{pH} \mathrm{7})$, recentrifuged for $25 \mathrm{~min}$ at $14000 \mathrm{rpm}$, removed the supernatant, redispersed in $1 \mathrm{ml}$ of a $2 \times$ PBS stock solution, stored at $4^{\circ} \mathrm{C}$, and diluted with equivalent MicroHyb buffer when used.

\section{Surface treatment of polypropylene slices}

The PP slices were cleaned in an acetone solution under supersonic waves, rinsed with water and dried under a vacuum. In order to link the amino functional group $\left(-\mathrm{NH}_{2}\right)$ on the surface of the PP slices, a plasma treatment was performed in a plasma producer with $100 \mathrm{~W}$ of discharge power, $2 \mathrm{~Pa}$ of vacuum, and a 2-min treating time. The gas flows of nitrogen and hydrogen were $50 \mathrm{ml} / \mathrm{min}$ and $100 \mathrm{ml} / \mathrm{min}$, respectively. The treated slices were dipped in a $5 \%$ glutaradehyde $/ 10 \mathrm{mM}$ PB solution for $2 \mathrm{~h}$, and rinsed with $10 \mathrm{mM}$ PB buffer and water. After being dried, the slices were immersed in a $10 \%$ hexamethylene diamine solution for $2 \mathrm{~h}$ at room temperature, washed thoroughly with water and dried prior to use.

In situ synthesis of DNA probes

DNA probes bound to grafted PP slices were in situ synthesized with an Expedite 8909 DNA synthesizer. The probe sequence was P2: 5'-TCA GTG CAT CGA TGT C-3'. The slice was deprotected in an ethanolamine/ethanol (1:1) solution at $76^{\circ} \mathrm{C}$ for $75 \mathrm{~min}$, and washed in $\mathrm{H}_{2} \mathrm{O}$.

\section{Hybridization of the sandwich assay format}

In one set of experiments, a solution of the complementary target, T0 (based on the cardiac muscle blocking sequence) in

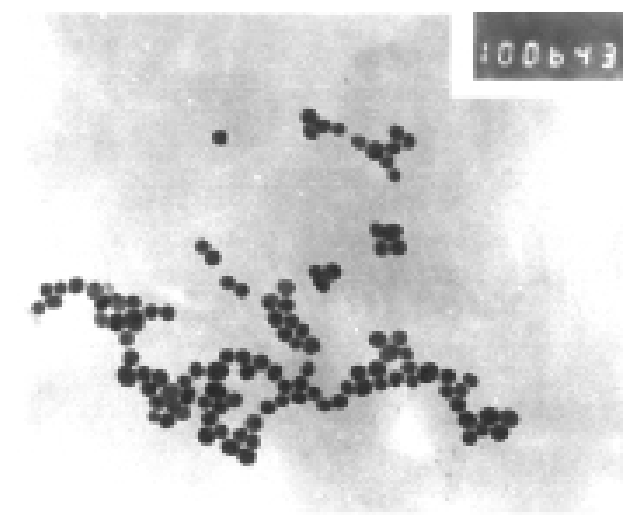

Fig. 1 TEM image of $13 \mathrm{~nm}$ Au nanoparticles.

MicroHyb buffer, was hybridized to an in situ synthesized oligonucleotide array for $4 \mathrm{~h}$ at $26^{\circ} \mathrm{C}$, washed with a $2 \times$ $\mathrm{SSC} / 0.1 \%$ SDS solution for $10 \mathrm{~min}$, then with a $0.1 \times \mathrm{SSC} / 0.1 \%$ SDS solution for $10 \mathrm{~min}$. Next, a solution of oligonucleotidefunctionalized gold nanoparticles was hybridized to the array for $4 \mathrm{~h}$ at $26^{\circ} \mathrm{C}$, washed with $2 \times \mathrm{SSC} / 0.1 \%$ SDS and $0.1 \times$ SSC/0.1\% SDS solutions respectively, and then washed with 2 $\times$ PBN $\left[0.3 \mathrm{M} \mathrm{NaNO}_{3}\right.$ and $10 \mathrm{mM} \mathrm{Na} \mathrm{HPO}_{4} / \mathrm{NaH}_{2} \mathrm{PO}_{4}$ buffer $(\mathrm{pH} 7)]$. The hybridized PP slice was submerged in a Silver Enhancer Solution (solutions of $0.5 \mathrm{~g} \mathrm{AgNO}_{3} / 2 \mathrm{ml} \mathrm{H} \mathrm{H}_{2} \mathrm{O}, 1.7 \mathrm{~g}$ hydroquinone $/ 30 \mathrm{ml} \mathrm{H}_{2} \mathrm{O}$ and $2.55 \mathrm{~g}$ citric acid/2.35 g trisodium citrate $/ 10 \mathrm{ml} \mathrm{H}_{2} \mathrm{O}$, mixed simultaneously) for $8 \mathrm{~min}$ at room temperature, and then washed with water. In another set of experiments, solutions of mismatched targets (T1, T2, T3) were hybridized to the synthesized oligonucleotide array, respectively. The procedure was entirely the same as that of a complementary target, T0.

\section{Results and Discussion}

\section{Sensitivity of hybridization system}

As a comparison, Figs. 2 and 3 showed the hybridization signals of in situ synthesized and spotted oligonucleotidefunctionalized polypropylene slices that were exposed to various concentrations of oligonucleotide targets, labeled with a nano-gold probe and immersed in a silver amplification solution, respectively. The grayscale values of the hybridization signals are shown in Fig. 4.

The target DNA at concentrations as low as $100 \mathrm{fM}$ was effectively distinguished from the background as the oligonucleotide (P1) was in situ synthesized onto the polypropylene slice surface, and the distinguishable concentration was about $100 \mathrm{pM}$ with spotting oligonucleotide (P1). The sensitivity of the in situ synthesis system was 3 orders of magnitude higher than that of the spotting system, and the signals of the former were about 2-times stronger than that of the latter under the same target DNA concentration. This may be attributed to that in situ synthesized oligonucleotides were more uniform and more stably bound to the substrate surface than the spotted ones, thus presenting a better hybridization circumstance and a higher hybridization efficiency.

\section{Specificity of the hybridization system}

The signals of different target DNA sequences with the same concentration of $100 \mathrm{fM}$ are shown in Fig. 5. T0, T1, T2 and T3 

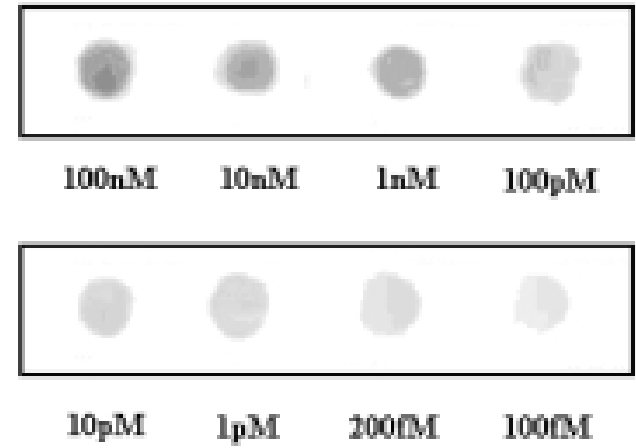

Fig. 2 Images of in situ synthesized oligonucleotide hybridization system; the concentrations of the complementary target DNA (T0) varied as indicated.

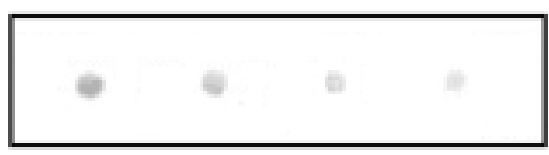

\section{$100 \mathrm{nM} \quad 10 \mathrm{nM} \quad \operatorname{lnM} \quad 100 \mathrm{pM}$}

Fig. 3 Images of the spotted oligonucleotide hybridization system; the concentrations of the complementary target DNA (T0) varied as indicated. The controlled conditions were the same as for the in situ synthesis system.

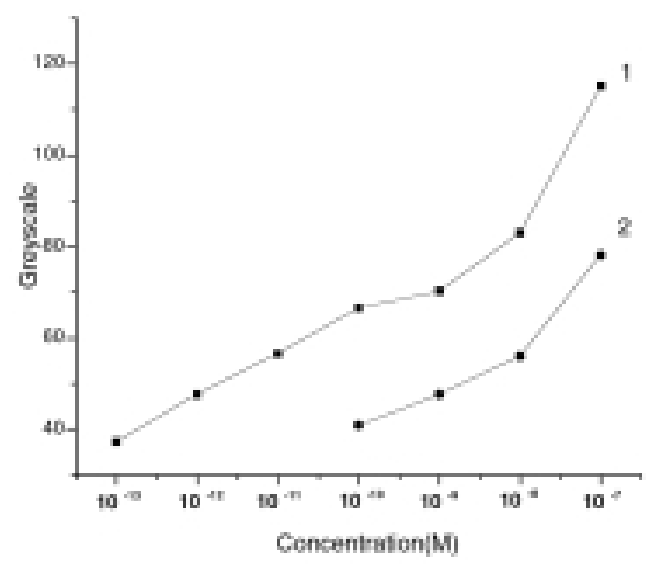

Fig. 4 Grayscale of in situ synthesized and spotted probe (P1)target (T0)-nanoparticle probe (P2)-silver amplified signals, obtained from histogram averages in Adobe Photoshop 7.0. 1, in situ synthesized probe; 2 , spotted probe.

represented a perfect match as well as 1-base, 2-base and 3-base mismatch sequences, respectively. The complementary and mismatched target DNA could be distinguished from the background baseline. The ratio of the background-subtracted gray-scale values for T0:T1:T2:T3 is 22:16:9:4.

\section{Conclusions}

In summary, we demonstrated that this new gene-detection system, which employs a plasma treatment on polypropylene slices and a DNA in situ synthesis technique based on colorimetric detection, has a sensitivity as low as $100 \mathrm{fM}$, and can clearly distinguish mismatch sequences at this target

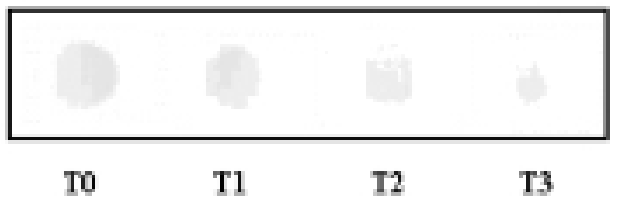

Fig. 5 Images of a different target DNA hybridization system at the same concentration of $100 \mathrm{fM}$.

concentration. The ratio of the background-subtracted grayscale values for a perfect match, single-base mismatch, 2-base mismatch and 3-base mismatch is 22:16:9:4. The sensitivity of in situ synthesis system was 3 orders of magnitude higher than that of the spotting system, and the signals of the former were about 2-times stronger than that of the latter under the same target DNA concentration. The dominant advantage is the simple plasma treatment used to graft amino groups onto the polypropylene substrate surface, compared with the complicated surface treatment in other gene-detective methods. The excellent chemical and mechanical properties, ready availability of polypropylene slices, no need for optical setups and the high sensitivity of gold label silver stain detective method make this detective system both novel and attractive.

\section{Acknowledgements}

This work was financially supported by the National Natural Science Foundation of China (No. 60071001, No. 60121101), 863 National High Tech Program of China (No. 2003AA302270) and Trans-Century Training Programme Foundation for the Talents by the Ministry of Education of China.

\section{References}

1. J. J. Storhoff, R. Elghanian, R. C. Mucic, C. A. Mirkin, and R. Letsinger, J. Am. Chem. Soc., 1998, 120, 1959.

2. K. C. Grabar, R. G. Freeman, M. B. Hommer, and M. J. Natan, Anal. Chem., 1995, 67, 735.

3. R. C. Mucic, J. J. Storhoff, C. A. Mirkin, and R. L. Letsinger, J. Am. Chem. Soc., 1998, 120, 12674.

4. T. A. Taton, C. A. Mirkin, and R. L. Letsinger, Science, 2000, 289, 1757.

5. C. A. Mirkin, R. L. Letsinger, R. C. Mucic, and J. J. Storhoff, Nature, 1996, 382, 607 .

6. R. Elghanian, J. J. Storhoff, R. C. Mucic, R. L. Letsinger, and C. A. Mirkin, Science, 1997, 277, 1078.

7. M. S. Mohy Eldin, M. Santucci, S. Rossi, U. Bencivenga, P. Canciglia, F. S. Gaeta, J. Tramper, A. E. M Janssen, C. G. P. H. Schroen, and D. G. Mita, J. Mol. Catal. B: Enzymatic, 2000, 8, 221.

8. M. S. Mohy Eldin, C. G. P. H. Schroen, A. E. M. Janssen, D. G. Mita, and J. Tramper, J. Mol. Catal. B: Enzymatic, 2000, 10, 445 .

9. P. Travascio, E. Zito, M. Portaccio, N. Diano, V. Grano, S. Di Martino, T. Bertolini, S. Rossi, and D. G. Mita, Biotechnol. Prog., 2002, 18, 975.

10. F. H. Isgrove, R. J. H. Williams, G. W. Niven, and A. T. Andrews, Enzyme Microb. Technol., 2001, 28, 225.

11. M. Kai, S. Kishida, and K. Sakai, Anal. Chim. Acta, 1999, 381,155 . 